\title{
POLSKA GMINA A MIĘDZYNARODOWE STANDARDY SAMORZAZDNOŚCI TERYTORIALNEJ (25 LAT W ZARYSIE)
}

Katarzyna Kobielska*

\author{
POLISH COMMUNE AND INTERNATIONAL LOCAL GOVERN- \\ MENT STANDARDS (THE LAST 25 YEARS - IN OUTLINE)
}

\section{- ABSTRACT}

The article presents the lowest level of local government - a commune - against the background of international local government standards formulated by such organizations as the Council of Europe, UNDP, OECD, the World Bank, the European Union. Firstly, the evolution of these standards is presented - starting from European Charter of Local Self-Government, through European Charter of Local Self-Government, ending with The Strategy for Innovation and Good Governance at Local Level and European Governance. Then, the range of implementation of these principles in Polish local government is analyzed. It can be determined that external influence in the form of international standards has been one of the key factors shaping the Polish self-government in the last 25 years.

KEYWORDS -

commune, international local government standards

* Uniwersytet Wrocławski, Instytut Politologii. 


\section{UWAGI WPROWADZAJACCE}

W niniejszym tekście podjęto próbę określenia znaczenia wpływów, jakim podlega polski samorząd gminny, płynących z otoczenia zewnętrznego. Pod pojęciem wpływów rozumiem standardy międzynarodowe dotyczące funkcjonowania władz i administracji lokalnej. Podstawowe podmioty stanowiące źródło tego rodzaju wpływów to Rada Europy i przygotowany przez nią - zawarty w Europejskiej Karcie Samorządu Lokalnego (EKSL) - katalog kryteriów, jakie powinna spełniać terytorialna samorządność.

Pomimo niewątpliwego znaczenia EKSL dla polskiej samorządności w niniejszym opracowaniu jest ona tylko punktem wyjścia. Staram się bowiem pójść dalej, prezentując trendy, które pojawiły się na przestrzeni kolejnych lat. W polskiej (i nie tylko polskiej) literaturze brakuje takiego ujęcia tematu, które traktuje opracowywane w kolejnych latach standardy samorządności jako proces podlegający stałemu rozwojowi. Ponadto trzeba przyznać, że sama EKSL stanowi zbiór wytycznych tak intensywnie eksploatowany w polskiej literaturze tematu ${ }^{1}$, że byłoby pewną niestosownością powielanie istniejących interpretacji pomimo deficytów, które nadal można zaobserwować w polskim systemie lokalnym. Poza samą EKSL zajmuję się więc wytycznymi bardziej nowoczesnymi, które odchodzą od przedstawiania decentralizacji jako jedynej oczywistej podstawy systemów demokratycznych (czy też aspirujących do bycia demokratycznymi), orientując się na jakość owej demokracji w jej warstwie funkcjonalnej.

1 Por. B. Dolnicki, Czy polskie ustawodawstwo samorzadowe odpowiada standardom europejskim?, „Samorząd Terytorialny” 1994, nr 9, s. 11-22; J. Galster, Ustawa samorządowa a europejskie standardy samorządności. Próba analizy komparatystycznej, „Zeszyty Naukowe WSHE” 1999, t. 4, s. 21-28; Z. Gilowska, L. Kieres, R. Sowiński, Samorząd terytorialny w Polsce a standardy europejskie, Warszawa 1993; L. Kieres, Analiza zgodności polskiego prawa samorządu terytorialnego z Europejska Karta Samorządu Terytorialnego, „Samorząd Terytorialny” 1998, nr 9, s. 1-80; Z. Niewiadomski, Samorząd terytorialny w Polsce na tle standardów europejskich, Materiał z konferencji z okazji 15-lecia samorządu terytorialnego w II Rzeczypospolitej Polskiej, Wrocław 2005, s. 5-9; A. Piekara, Doctrinal Inspirations and the Charter of Local Government versus the Present Day Model of Local Governance in Poland, Warszawa 2003; T. Szewc, Formy realizacji prawa do samorzadu w Europejskiej Karcie Samorzadu Terytorialnego, „Państwo i Prawo” 2004, z. 7, s. 53-58; idem, Model samorzadu terytorialnego a standardy europejskie (15 lat po ratyfikacji Europejskiej Karty Samorządu Lokalnego), [w:] Samorząd terytorialny. Ale jaki?, red. A. Lutrzykowski, Toruń 2009; T. Szewc, Samorzad terytorialny w pracach Rady Europy: (wybrane zagadnienia), „Samorząd Terytorialny” 2007, nr 1-2, s. 5-14; P. Teklak, Obowiązywanie, wykładnia oraz realizacja Europejskiej Karty Samorządu terytorialnego w polskim porzadku prawnym, www.bibliotekacyfrowa.pl/Content/42873/07_Piotr_Tetlak.pdf, odczyt $\mathrm{z}$ dn. 15.01.2015. 


\section{EWOLUCJA MIĘDZYNARODOWYCH STANDARDÓW SAMORZĄDNOŚCI TERYTORIALNEJ}

Standard to według Nowego słownika języka polskiego powszechnie przyjęty, przeciętny model. Jest to wspólnie ustalone kryterium/zestaw kryteriów, które określa powszechne, zwykle najbardziej pożądane cechy czegoś. Standard to także podstawowa, najprostsza wersja czegoś2 ${ }^{2}$ W efekcie jest to wzór-minimum, do którego dążą ci, którzy chcą osiągnąć lepszą jakość. Standardy w stosunkach społecznych tworzy się w oparciu o wiedzę o danym zjawisku, doświadczenie, praktykę, sprawdzalność. Nie inaczej było i jest w przypadku wzorców dotyczących funkcjonowania samorządów terytorialnych. Po kilkudziesięciu latach (1952-1985) debat, wymiany doświadczeń, obserwacji samorządowej rzeczywistości na arenie międzynarodowej pojawiły się podstawowe kryteria dotyczące niezbędnych kryteriów samorządności terytorialnej.

Uzasadnione wydaje się w tym miejscu postawienie pytania, do czego właściwie takie standardy są potrzebne? Poszczególni ich adresaci mogą wskazać różne ich zalety. Władze ponadlokalne (narodowe) potrzebują standardów, aby stworzyć właściwy strukturalnie i funkcjonalnie system - ramy, w których działać będą władze lokalne oraz układać się będą ich wzajemne relacje. Lokalne władze mogą wykorzystać istniejące wzory do tworzenia lepszych warunków dla własnej aktywności. Administracja publiczna (lokalna) potrzebuje standardów, aby realizować swoje funkcje na optymalnym poziomie. Obywatele, odwołując się do nich, mogą weryfikować sposób postępowania władz oraz działalność administracji. Dostarczają im możliwych do wykorzystania w praktyce mierników. Jerzy Regulski, podsumowując swoją działalność w Radzie Europy, zwrócił uwagę na znaczenie funkcjonowania w środowisku międzynarodowym oraz dostosowania się (integracji) do tamtejszego dorobku jako strategiczny cel polityki polskiej. „Integracja wymaga jednak dostosowania własnych struktur prawnych, instytucjonalnych i społecznych do modeli, istniejących w tych państwach, z którymi chcemy nawiązać bliską współpracę. Aby się zintegrować, trzeba się odpowiednio upodobnić. Przy daleko idących zróżnicowaniach instytucjonalnych współpraca jest bardzo trudna, a integracja niemożliwa”3.

2 Standard, [w:] Nowy słownik języka polskiego, Warszawa 2003, s. 954.

3 J. Regulski, 5 lat w Radzie Europy. Garść wspomnień i refleksji, Warszawa 1998, s. 85. 
Za najbardziej powszechny katalog standardów dotyczących samorządności terytorialnej należy uznać samą Europejską Kartę Samorządu Lokalnego ${ }^{4}$. W EKSL została zdefiniowana samorządność terytorialna oraz brzegowe warunki funkcjonowania. W jej świetle samorząd oznacza prawo i faktyczną możność społeczności lokalnych do regulowania i kształtowania, w ramach ustaw, znacznej części spraw publicznych na własną odpowiedzialność dla dobra mieszkańców. Ponadto w EKSL pojawiły się takie wytyczne, jak: 1) osadzenie samorządności lokalnej w wewnętrznych ramach prawnych (w miarę możliwości na poziomie konstytucji); 2) przypisanie pakietu kompetencji na poziomie ustawowym; 3) ramy prowadzenia nadzoru nad samorządem; 4) funkcjonowanie wybieralnych władz; 5) wewnętrzne organizowanie sieci administracji lokalnej jako aparatu wykonawczego; 6) zapewnienie systemu finansowego, adekwatnego do obowiązków spoczywających na władzach i administracji lokalnej - zarówno na poziomie możliwości dysponowania środkami własnymi, jak i organizacji systemu subsydiowania prowadzonej działalności; 7) prawo do zrzeszania się na poziomie zarówno krajowym, jak i ponadnarodowym.

Na kanwie aktywności Rady Europy ${ }^{5}$ tematyka dotycząca uwarunkowań funkcjonowania władz lokalnych zajęła stałe miejsce w debacie ponadnarodowej $^{6}$.Z czasem podjęły ją organizacje międzynarodowe, które rozszerzyły swoją aktywność na płaszczyzny związane z funkcjonowaniem społeczności lokalnych. I tak Organizacja Narodów Zjednoczonych od początku lat dziewięćdziesiątych promuje DLG - Democratic Local Governance ${ }^{7}$. Organizacja Współpracy Gospodarczej i Rozwoju (OECD) i Bank Światowy ${ }^{8}$ w podobnym czasie zaczęły akcentować jakość rządzenia (good governance) - również w wymiarze lokalnym Good governance to także zbiór wymogów, stawianych przez Komisję Europejską

${ }^{4}$ European Charter of Local Self-Government, Council of Europe, European Treaty Series No. 122, Strasbourg, 15.10.1985.

5 Rada Europy w 1997 r. przygotowała także drugi istotny zbiór standardów odnoszących się do wyższego szczebla samorządu - Europejską Kartę Samorządu Regionalnego.

${ }^{6}$ W tym samym czasie przygotowana została Światowa Deklaracja Samorządu Lokalnego uchwalona na 27 Światowym Kongresie Międzynarodowego Związku Władz Lokalnych w dniach 22-26 września 1985 r. w Rio de Janeiro, stanowiąca zbiór zasad, według których ma działać samorząd terytorialny.

7 H. Blair, Participation and Accountability at the Periphery: Democratic Local Governance in Six Countries, „World Development” 2000, Vol. 28, No. 1, s. 22.

8 Wskaźniki Banku Światowego, http://info.worldbank.org/governance/wgi/index.aspx\#doc, odczyt z dn. 15.12.2014.

9 J. Ahrens, Governance, conditionality and the transformation of post-socialist countries, [w:] H.W. Hoen [et al.], Governance Structures in Central and Eastern Europe, Groningen 2000, s. 43-72. 
wobec administracji działającej na terenie UE, określony w European Governance a White Paper ${ }^{10}$. Także Rada Europy sformułowała „nowocześniejszą” propozycję kierowania sprawami publicznymi przez samorządy - Strategy for Innovation and Good Governance at Local Level ${ }^{11}$.

Działalność Rady Europy - od EKSL, poprzez Europejską Kartę Samorządu Regionalnego (1997), aż po Strategy for Innovation and Good Governance at Local Level - najwyraźniej eksponuje zmiany, jakie dokonały się w środowisku międzynarodowym w zakresie wizji (standardów) lokalnej samorządności. Okazuje się bowiem, że kwestie kształtowania warunków decentralizacji (politycznej, finansowej i administracyjnej) - eksponowane na początku - na początku XXI wieku stanowią katalog wytycznych na tyle oczywistych, że formułowane są standardy dalej idące ${ }^{12}$. Sprowadzają się one, najogólniej rzecz ujmując, do kategorii (local) governance, która traktowana jest jako nowy paradygmat rozwoju ${ }^{13}$, akcentujący znaczenie rezultatów rządzenia, czyli zdolność do działania satysfakcjonującego tych, w imieniu których i dla których podejmowane są wiążące decyzje $\mathrm{e}^{14}$. W Strategy for Innovation and Good Governance at Local Level zawarto dwanaście zasad, które czynić mają samorządy bardziej innowacyjnymi i „współzarządzanymi”: 1) Uczciwe wybory, reprezentacja i partycypacja; 2) Responsywność; 3) Efektywność, w tym skuteczność; 4) Otwartość i przejrzystość; 5) Praworządność;

10 European Governance a White Paper, Commission of the European Communities, Brussels, 25.07.2001, COM(2001)428. W dokumencie tym zaproponowano następujące zasady dobrego rządzenia: otwartość, partycypację, skuteczność, efektywność, rozliczalność oraz spójność.

11 Strategy for Innovation and Good Governance at Local Level, przygotowana w 2007 roku, a podpisana przez Komitet Ministrów Rady Europy w roku 2008, www.coe.int/t/dgap/localdemocracy/Strategy_Innovation/, odczyt z dn. 20.12.2014.

12 A. Shah, F. Shah, Citizen-centred Local Governance: Strategies to combat democratic deficit, „Development” 2007, Vol. 50, Issue 1, s. 78.

13 Por. T. Borys, Koncepcja dobrego rzadzenia - istota, cechy swoiste i pomiar, [w:] Dobre rzadzenie w gminach małych. Empiryczny wymiar nowego paradygmatu rozwoju, red. K. Kobielska, A. Lisowska, Bydgoszcz 2014, s. 52-70.

14 Por. R.A.W. Rhodes, The New Governance: Governing without Government, „Political Studies” 1996, Vol. 44, Issue 4; idem, Understanding Governance. Policy, Networks, Governance, Reflexivity and Accountability, Philadelphia 1997; G. Stoker, Governance as theory: five propositions, „International Social Science Journal" 1998, Vol. 50, s. 17-28; P. John, Local Governance in Western Europe, London-Thousand Oaks 2001; A.M. Kjær, Rządzenie, Warszawa 2009, s. 35-43; M. Popławski, Governance wedtug Rona A.W. Rhodesa - Konieczność zastosowania w Polsce na szczeblu lokalnym?, [w:] Samorzad terytorialny na przełomie XX/XXI wieku, red. A. Lutrzykowski, R. Gawłowski, M. Popławski, Toruń 2010, s. 113-122; K. Radzik, Lokalne wspótzarządzanie (local governance) w polskim samorządzie terytorialnym - mit czy realna perspektywa?, [w:] XX lat samorządu terytorialnego w Polsce. Doświadczenia - problem - perspektywy, red. J. Kowalik, A. Bednarz, Toruń 2011, s. 213-230. 
6) Etyczne postępowanie; 7) Kompetencje; 8) Innowacyjność i otwartość na zmiany; 9) Zrównoważony rozwój i długoterminowość w planowaniu polityk lokalnych; 10) Racjonalne gospodarowanie lokalnymi środkami publicznymi; 11) Respektowanie praw człowieka, kulturowej różnorodności oraz społecznej inkluzji; 12) Rozliczalność.

Zaproponowany katalog obejmuje szeroki zakres problematyki dotyczącej jakości władztwa lokalnego, wskazując kryteria, które będą czyniły owo władztwo skutecznym i zarazem otwartym na obywatela. Zestawienie to koresponduje z wymogami stawianymi przez organizacje, które udzielają wsparcia (finansowego czy organizacyjnego), np. ONZ czy Bank Światowy, na przedsięwzięcia wyraźnie nawiązujące do paradygmatu governance ${ }^{15}$. Jednocześnie trzeba także stwierdzić, że w tym nowym wydaniu „warunki brzegowe” demokracji lokalnej, określone w EKSL, nakierowują samorządy na rozwój w sferze szeroko rozumianych kompetencji wykonawczych i umacniania demokratycznych relacji z obywatelami. Koresponduje to $\mathrm{z}$ nowymi koncepcjami funkcjonowania sektora publicznego, silnie akcentującymi governance (New Modes of Governance ${ }^{16}$ ), nie pozbawiając go jednak wątków charakterystycznych dla New Public Management ${ }^{17}$ (co przejawia się w odniesieniach do efektywności oraz skuteczności podejmowanych działań) ${ }^{18}$.

\section{POLSKA GMINA I MIĘDZYNARODOWE STANDARDY SAMORZĄDNOŚCI}

Analiza przemian, jakie następowały w obszarze kształtowania się polskiej samorządności, pozwala wyodrębnić dwa główne przedziały czasowe. Pierwszy to lata 1990-2002, który można określić mianem budowy struktur, „zmian sys-

15 A Users' Guide to Measuring Local Governance, UNDP, Oslo 2011.

16 A. Heritier, M. Rhodes, New Modes of Governance in Europe. Governing in the Shadow of Hierarchy, London-New York 2010; A. Héritier, D. Lehmkuhl, New Modes of Governance and Democratic Accountability, „Government and Opposition” 2011, Vol. 46, Issue 1, s. 126-144; A. Matheson, Modernizacja sektora publicznego: nowy program. Przegląd dwóch dekad modernizacji z perspektywy zarzadzania zasobami ludzkimi, [w:] Administracja publiczna. Wyzwania w dobie integracji europejskiej, red. J. Czaputowicz, Warszawa 2008, s. 66-81.

17 Por. Nowe zarzadzanie publiczne $w$ polskim samorzadzie terytorialnym, red. A. Zalewski, Warszawa 2005; M. Zawicki, Nowe zarządzanie publiczne, Warszawa 2014.

18 A. Vetterm, N. Kersting, Democracy versus efficiency? Comparing local government across Europe, [w:] Reforming Local Government in Europe. Closing the Gap between Democracy and Efficiency, red. N. Kersting, A. Vetter, Opladen 2003, s. 11-28. 
temowych”, drugi (2003-2015) to czas „zmian operacyjnych” - zorientowanych na doskonalenie $\mathrm{w}$ warstwie wykonawczej. W tym pierwszym okresie polska klasa polityczna uczyła się samorządności w swoim najbliższym otoczeniu, zaś politycy szczebla centralnego formułowali założenia reformy terytorialnej, co nastąpiło w roku 1998. W latach kolejnych miało miejsce utrwalenie ukształtowanego podziału terytorialnego oraz relacji pomiędzy poszczególnymi szczeblami samorządu.

Polska, rozpoczynając przemiany systemowe, podjęła wysiłek sprostania podstawowym standardom decentralizacji określonym w EKSL. Okazuje się jednak, że wytyczne te zostały wdrożone w niepełnym zakresie (tabela 1). Tam, gdzie było to łatwe, bo sprowadzało się do ogólnych założeń czy wytycznych, jak w przypadku konstytucyjnego umocowania samorządności terytorialnej, standardy zostały zrealizowane. Tam, gdzie wymagane jest działanie o charakterze operacyjnym - jak w przypadku materialnych środków prawnych czy możliwości kreowania struktur administracyjnych - istnieje stała tendencja do centralnego oddziaływania na samorząd i sytuacja nie ulega tutaj zmianie od lat. Za dominujący w tym względzie można uznać model dekoncentracji i delegowania ${ }^{19}$ uprawnień, nie zaś dewolucji ${ }^{20}$. W przypadku, gdy w grę wchodziły pieniądze, w zasadzie od samego początku brakowało woli i/lub odwagi politycznej, aby zreformować system ${ }^{21}$.W kategoriach regresu rozpatrywane są natomiast skutki reformy z 2002 roku, w wyniku której w gminie ukonstytuował się monokratyczny organ wykonawczy wybierany bezpośrednio przez obywateli ${ }^{22}$.

Lata 2003-2015 to czas „europeizacji” ${ }^{23}$ samorządu, przejawiającej się zarówno w wymiarze instytucjonalnym, jak i w kontekście podniesienia jakości

19 Por. L. Habuda, Decentralizacja vs centralizacja administracji w strukturze zasadniczego terytorialnego podziału kraju, Toruń 2009, s. 153-175; J. Niczyporuk, Dekoncentracja administracji publicznej, Lublin 2006.

${ }^{20}$ Ch. Pollitt, Decentralization. A Central Concept in Contemporary Public Management, [w:] The Oxford Handbook of Public Management, red. E. Ferlie, L.E. Lynn Jr., Ch. Pollitt, Oxford 2005, s. $374-376$.

21 Por. A. Kopańska, Efektywność decentralizacji. Analiza zdecentralizowanego dostarczania dóbr o charakterze ponadlokalnym, Warszawa 2014, s. 49-98.

22 M. Kasiński, Monizm i pluralizm władzy lokalnej. Studium prawno-polityczne, Łódź 2010, s. $361-490$.

23 Analizy prowadzone nad europeizacją administracji publicznej wyodrębniają dwa podejścia. Pierwsze przewiduje wprowadzenie (docelowo) jednego uniwersalnego modelu administracji publicznej, drugie przewiduje wprowadzenie systemu wspólnych wartości (podstawowych zadań oraz standardów jakościowych). Por. G. Rydlewski, Problemy europeizacji administracji publicznej, [w:] Administracja publiczna..., op.cit., s. 100-101. 
Tabela 1. Poziom realizacji wybranych kryteriów EKSL w polskim (lokalnym) systemie politycznym

\begin{tabular}{|c|c|c|c|c|c|c|}
\hline \multirow[b]{2}{*}{ Lp. } & \multirow[b]{2}{*}{ KRYTERIUM } & \multicolumn{5}{|c|}{$\begin{array}{l}\text { POZIOM SPEŁNIENIA } \\
\text { KRYTERIUM }\end{array}$} \\
\hline & & 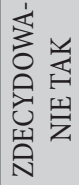 & 䓛 & 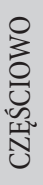 & 䛼 & 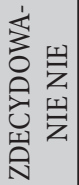 \\
\hline 1. & Uznanie samorządności terytorialnej w prawie wewnętrznym & $\mathrm{X}$ & & & & \\
\hline 2. & $\begin{array}{l}\text { Przekazanie zadań i kompetencji w drodze ustawowej } \\
\text { (w sposób trwały) }\end{array}$ & $\mathrm{X}$ & & & & \\
\hline 3. & $\begin{array}{l}\text { Przekazanie samorządowi terytorialnemu „istotnej” części } \\
\text { zadań publicznych }\end{array}$ & $\mathrm{X}$ & & & & \\
\hline 4. & Sądowa ochrona wykonywania uprawnień samorządu & & $\mathrm{X}$ & & & \\
\hline 5. & $\begin{array}{l}\text { Wyposażenie samorządów w środki materialne (prawne) } \\
\text { skutecznej realizacji zadań }\end{array}$ & & & & $\mathrm{X}^{*}$ & \\
\hline 6. & Zabezpieczenie materialnych środków realizacji zadań & & & & & $\mathrm{X}^{* *}$ \\
\hline 7. & $\begin{array}{l}\text { Samodzielność w zakresie ustalania struktur } \\
\text { administracyjnych }\end{array}$ & & & $\mathrm{X}$ & & \\
\hline 8. & $\begin{array}{l}\text { Zasady wykonywania funkcji reprezentantów wybieranych do } \\
\operatorname{rad} \text { (imcompabilitas, warunki wykonywania pracy) }\end{array}$ & & & & $\mathrm{X}$ & \\
\hline 9. & $\begin{array}{c}\text { Ponoszenie odpowiedzialności przez organy wykonawcze } \\
\text { przed radami (zgromadzeniami) }\end{array}$ & & & & & $\mathrm{X}$ \\
\hline 10. & Wysoka jakość kadr administracji samorządowej & & & X & & \\
\hline 11. & Nadzór nad samorządem terytorialnym & & & $\mathrm{X}$ & & \\
\hline 12. & Prawo do zrzeszania się JST & & X & & & \\
\hline
\end{tabular}

* W tym aspekcie dominuje model umożliwiający wydawanie aktów o charakterze stricte wykonawczym. Zygmunt Niewiadomski podkreśla znaczenie braku możliwości samodzielnego stanowienia prawa lokalnego. Jego zdaniem stopień samodzielności polskiej gminy jest tutaj niewspółmiernie niski w stosunku do zakresu zadań. Por. Z. Niewiadomski, Samorząd terytorialny ..., op. cit., s. 7; T. Szewc, Model samorzadu terytorialnego..., op. cit., s. 155-157.

** Samodzielności finansowej nie sprzyja prymat dotacji celowych nad ogólnymi. Por. Z. Niewiadomski, Samorzą terytorialny..., op. cit., s. 6.

Źródło: opracowanie własne na podstawie przywołanej we wstępie literatury. 
życia mieszkańców. Początkowo, w latach 2000-200724, samorządy przysposabiały się do absorpcji unijnej pomocy. Od 2008 roku w sposób pełnowymiarowy zaczęły korzystać z dobrodziejstwa własnego zacofania (regionalnego) - na tej bowiem podstawie mogły pozyskać wsparcie na wyrównywanie dysproporcji rozwojowych. Pomoc obejmowała również niwelowanie różnic na poziomie instytucjonalnym - w zakresie funkcjonowania struktur państwa, w tym także samorządu. Przede wszystkim jednak wsparciem objęty został aparat wykonawczy (administracja). W ten sposób w 2008 roku Polska rozpoczęła implementację wytycznych przybliżających administrację do standardów unijnych, które w swym ogólnym zarysie opierają się na European Governance a White Paper przygotowanej przez Komisję Europejską. W konsekwencji nastąpiła implementacja kryteriów formułowanych na poziomie unijnym.

Dokumentem operacjonalizującym zasady wsparcia zmian instytucjonalnych w samorządach w latach 2007-201325 był Program Operacyjny Kapitał Ludzki (PO KL). Wyodrębniono tam Priorytet V „Dobre rządzenie”, w którym przewidziano wsparcie dla lokalnych korporacji samorządowych, wynoszące ponad 213,1 mln EUR ${ }^{26}$. Pomoc ta została przeznaczona na wzmocnienie potencjału administracji samorządowej w takich obszarach, jak:

1) poprawa jakości prawa miejscowego i indywidualnych decyzji administracyjnych organów jednostek samorządu terytorialnego,

2) poprawa skuteczności i efektywności wykonywania zadań publicznych przez jednostki samorządu terytorialnego,

3) podniesienie zaufania społecznego do władz lokalnych i regionalnych poprzez poprawę przejrzystości działań administracji samorządowej oraz zwiększenie wpływu mieszkańców i instytucji społeczeństwa obywatelskiego na proces decyzyjny organów jednostek samorządu terytorialnego.

W praktyce każda jednostka samorządu terytorialnego (JST) - aplikujący projektodawca - musiała wpisywać się w wytyczone filary dobrego rządzenia, osiągając co najmniej jeden rezultat w każdym z nich:

${ }^{24}$ Uwzględnić tutaj należy zarówno okres przedakcesyjny, kiedy uruchomione zostało wsparcie (w ramach funduszy: PHARE, SAPARD, ISPA) dla samorządów, jak i pierwsze lata pełnowymiarowego członkostwa Polski (w ramach starego okresu budżetowania) - 2004-2006.

25 A. Podgórniak-Krzykacz, Dobre rządzenie w teorii i praktyce zarządzania strategicznego, „Studia Ekonomiczne" 2013, nr 169, s. 170.

26 Barometr rozwoju instytucjonalnego jednostek samorządu terytorialnego, Raport $\mathrm{z}$ badania, Warszawa 2013, s. 98, http://www.ip.mac.gov.pl/ip2/dokumenty/badania-i-raporty/badania-ewaluacyjne, odczyt z dn. 10.12.2014. 
Filar I: Państwo prawa - obejmujący działania zmniejszające liczbę uchwał JST uchylonych przez wojewodę/Regionalną Izbę Obrachunkową/Samorządowe Kolegium Odwoławcze oraz liczbę decyzji administracyjnych wydawanych po upływie terminów określonych w kodeksie postępowania administracyjnego.

Filar II: Skuteczność i efektywność - obejmujący działania służące poprawie zarządzania w JST i jakości świadczonych usług publicznych np. poprzez: wdrożenie i rozwój systemu zarządzania jakością, wdrożenie systemu monitorowania i ewaluacji strategii rozwoju lub planów wykonawczych do strategii rozwoju, wdrożenie systemu monitorowania usług publicznych lub udział w badaniach Systemu Analiz Samorządowych i poprawę wskaźników jakości świadczonych usług, wdrożenie systemu rozwoju kompetencji kadr opartego na badaniu luk kompetencyjnych i potrzeb szkoleniowych pracowników urzędu na podstawie aktualnych opisów stanowisk, zwiększenie skuteczności poboru opłat i podatków lokalnych.

Filar III: Partycypacja i przejrzystość - obejmujący działania służące wzrostowi zaufania społecznego: usprawnienie/wdrożenie procedury konsultacji społecznych i wzrost liczby konsultacji, opracowanie i wdrożenie procedury aktualizowania „mapy aktywności” organizacji pozarządowych, wdrożenie zasad przejrzystości urzędu poprzez regularne publikowanie danych w Biuletynie Informacji Publicznej (BIP), opracowanie i wdrożenie procedury aktualizowania opisu usług świadczonych w JST, dostępnych w BIP lub w biurze (wydziale) obsługi klientów (mieszkańców), przyjęcie kodeksu etycznego pracowników urzędu gminy (miasta) itp.

$\mathrm{Na}$ przestrzeni minionych lat ze wsparcia, o którym wyżej, skorzystała ponad połowa polskich gmin - 51,2\%. Pomijając kwestie jego skuteczności i zasadności ${ }^{27}$, które same w sobie stanowią ciekawy przedmiot badawczy, zwrócić należy uwagę na trzy istotne kwestie. Po pierwsze, należy stwierdzić, iż implementowane kierunki wsparcia wpisują się w międzynarodowe standardy funkcjonowania samorządowej sfery publicznej. Znajduje to swoje potwierdzenie zarówno w odniesieniu do Strategy for Innovation and Good Governance at Local Level, unijnej European Governance a White Paper, jak i koncepcji Democratic Local Governance. Po drugie, osiągnięty rozwój instytucjonalny ma wyraźnie egzogeniczne podstawy i wymiar, co przejawia się w osiąganych/nakładanych wskaźnikach, np.: pierwotnej certyfikacji/modernizacji systemu zarządzania

27 Ibidem. 
ISO, wdrożeniu Powszechnego Modelu Oceny CAF, wdrożeniu Programu Rozwoju Instytucjonalnego PRI, BSC, EFQM. Taka formuła budzi wątpliwość co do adekwatności, a przede wszystkim trwałości osiągniętych wskaźników (większość urzędów gmin, które kilka lat temu zdecydowały się na ISO, dzisiaj rezygnuje $z$ kolejnych certyfikacji). Po trzecie, wzmocnienie instytucjonalne obejmuje przede wszystkim urzędników - z systemu wsparcia wyłączeni są np. radni gminni.

Czas pokaże trwałość wdrożonych rozwiązań, szczególnie w kontekście nowej perspektywy finansowej (2014-2020), w którą wkroczyły polskie gminy. Przewidziano tam bowiem nieco inną orientację, obejmującą implementację rozwiązań poprawiających efektywność zarządzania usługami dziedzinowymi zarządzaniem nieruchomościami, obsługą systemu podatków i opłat lokalnych, planowaniem przestrzennym oraz obsługą przedsiębiorców/inwestorów. Tym samym nastąpi odwrót od kształtowania kompetencji i umiejętności o charakterze ogólnym na rzecz większej specjalizacji (jakkolwiek obejmującej cztery wskazane obszary).

\section{UWAGI KOŃCOWE}

Analizując określone standardy, trzeba raz jeszcze podkreślić, że nie są one niczym wyrafinowanym, nie stanowią jakości najwyższej - są podstawą i wzorem-minimum. Czy więc polska gmina wpisuje się w międzynarodowe standardy z zakresu samorządności terytorialnej? Cel, jaki postawiono przed zawartymi w niniejszym artykule rozważaniami, sprowadzał się do poszukiwania odpowiedzi na pytanie o znaczenie wpływu standardów międzynarodowych na polski samorząd gminny na przestrzeni minionego ćwierćwiecza. Wyniki przeprowadzonej analizy sprawiają, że trudno jest postawić odpowiedź jednoznacznie wartościującą, ponieważ na przestrzeni analizowanych lat wystąpiły zarówno przesłanki świadczące o silnym respektowaniu trendów międzynarodowych (ze szczególnym uwzględnieniem kryteriów unijnych), jak i wskazujące na wiele niedociągnięć o charakterze podstawowym. Wśród tych pierwszych wskazać trzeba, że:

1) Przedmiotowa problematyka zaistniała w polskim środowisku naukowym już w latach osiemdziesiątych XX wieku. Zanim jeszcze gmina została powołana do życia, reprezentacja z Polski podjęła współpracę w ramach Rady Europy. Aktywność ta dała istotny wkład w kształtowanie samo- 
rządności terytorialnej w latach 1989-1990 i następnych ${ }^{28}$. Tym samym należy stwierdzić, że zaistniały zarówno wiedza, jak i świadomość potrzeby kształtowania samorządności w oparciu o sprawdzone wzory.

2) Niemal na wejściu przyjęto silną podstawę formalną potwierdzającą respektowanie standardów międzynarodowych - polski ustawodawca, ratyfikując EKSL, nadał jej rangę elementu państwowego porządku prawnego. Oznacza to, że nie tylko na poziomie deklaratywnym wystąpiła chęć decentralizacji (dewolucji) systemu.

3) W pierwszej fazie reformowania samorządu terytorialnego w Polsce (1990-2002) poczyniono spory wysiłek organizatorski zmierzający do nadania samorządowi kształtu i uprawnień, które pozwoliłyby działać we własnym zakresie i na własną odpowiedzialność. W jej pierwszym etapie skoncentrowano się na kwestiach podstawowych w zakresie: uregulowań prawnych i kompetencyjnych, mienia komunalnego, finansów lokalnych, pracowników samorządowych ${ }^{29}$. W drugim etapie skupiono się na przygotowaniu i przeprowadzeniu reformy podziału terytorialnego kraju. Działania podjęte w pierwszym etapie, szczególnie w konfrontacji z sytuacją sprzed 1990 roku, wyraźnie świadczą o dążeniu do osiągnięcia wzoru - minimum określonego w EKSL.

4) Działania podejmowane w fazie europeizacji samorządów można zakwalifikować jako próbę osiągania standardów międzynarodowych zgodnie z obowiązującymi w tym czasie trendami doskonalenia sfery publicznej w nurcie governance. Obecnie polski samorząd gminny nadal znajduje się $\mathrm{w}$ fazie europeizacji. Ma to silny związek $\mathrm{z}$ absorpcją wsparcia unijnego, które w latach 2014-2020 akcentuje konkurencyjność, innowacje oraz konsolidację, jakkolwiek presja zewnętrzna (zachęty), związana z doskonaleniem jakości administracji wykonawczej, nie jest już tak silna ${ }^{30}$.

Niedociągnięcia, na które można zwrócić uwagę, mają równie istotne znaczenie, jeśli nie większe, gdyż stymulować powinny do działań na rzecz modernizacji systemu w Polsce. Przede wszystkim przywołać można trafną i wciąż aktualną konstatację Michała Kuleszy sprzed blisko dziesięciu lat: „[...] decentralizacja przestaje być jedynie [...] aktem dobrej woli oświeconej władzy centralnej,

28 Por. J. Regulski, Samorzad III..., op.cit., s. 28-46; J. Emilewicz, A. Wołek, Reformatorzy i politycy. Gra o reformę ustrojową roku 1998 widziana oczami jej aktorów, Warszawa 2000, s. 25-33.

${ }^{29}$ Por. J. Regulski, Samorząd III..., op.cit., s. 185-312.

30 Local Government in Critical Times: Policies for Crisis, Recovery and Sustainable Future, red. K. Davey, Strasbourg 2011. 
lecz staje się koniecznym, cywilizacyjnym warunkiem właściwego zarządzania sprawami publicznymi" ${ }^{31}$. Cóż więc z tego, że na poziomie doktrynalnym funkcjonuje system zdecentralizowany, werbalnie odpowiadający wzorcom międzynarodowym, kiedy do uregulowania jest jeszcze wiele spraw o charakterze esencjonalnym. Odnoszą się one zarówno do kwestii ustrojowych (np. potrzeba wprowadzenia modelu zarządzania przez radę, wzmocnienie pozycji rady i radnych w zarządzaniu JST, odejście od zasady niepołączalności mandatu radnego i posła), finansów publicznych (np. wypracowanie nowego systemu dochodów komunalnych, konsolidacja centralnych uprawnień decyzyjnych w sferze finansów komunalnych, budowa samorządowej infrastruktury finansowej), jak i zarządczych (np. podniesienie jakości nadzoru nad JST, uporządkowanie regulacji dotyczących działalności spółek komunalnych) ${ }^{32}$.

Co przyniesie przyszłość? Istnieje dość duże prawdopodobieństwo, że $\mathrm{w}$ odniesieniu do gminy - niewiele, w każdym razie nie będą to działania podyktowane interesem gminnym. Można nawet zaryzykować stwierdzenie, że w nadchodzącej dziesięciolatce gmina może doznać pewnego uszczerbku własnego statusu. Wniosek taki wynika z dwóch przesłanek. Po pierwsze, dość powszechne są głosy dotyczące potrzeby konsolidacji gmin (także w warunkach europejskich). Przy pełnej niechęci politycznej i organizacyjnej „dołów” proces ten już się rozpoczął - rękami Unii Europejskiej, władz centralnych oraz samorządowych władz regionalnych. Chodzi mianowicie o środki unijne uruchamiane w ramach tzw. Zintegrowanych Inwestycji Terytorialnych. Konstrukcja tego tworu obliguje gminy do współpracy - generowania wspólnych projektów społecznych oraz infrastrukturalnych, tworzenia wspólnego systemu zarządzania przedsięwzięciami. Można więc powiedzieć, że mamy tutaj do czynienia ze swoistym pilotażem konsolidacji samorządów. Po drugie, już dzisiaj pobrzmiewają głosy dotyczące pilnej potrzeby redefinicji, a co za tym idzie działań systemowych, które pozwoliłyby na nowo określić status samorządowego województwa po roku 2020. Będzie to skutek zmian zapowiadanych w finansowaniu polityki regionalnej. Jest wielce prawdopodobne, że to właśnie na tej kwestii skupi się uwaga polityczna. Tym samym kwestie gminne - wymagające pilnych reform - zejdą na plan dalszy. Prognozowane zmiany to w dużej mierze wpływ ten-

31 M. Kulesza, Państwo - Obywatel - Samorząd, „Samorząd Terytorialny” 2007, nr 8, s. 11.

${ }^{32}$ Narastające dysfunkcje, zasadnicze dylematy, konieczne działania. Raport o stanie samorzadności terytorialnej w Polsce, t. II, Kraków 2014, http://www.msap.uek.krakow.pl/doki/publ/raport_dysfunkcje.pdf, odczyt $\mathrm{z}$ dn. 15.01.2015. 
dencji ponadnarodowych, głównie unijnych, podyktowanych pragmatyzmem związanym z chęcią wykorzystania szans rozwojowych.

Podsumowując, nieco prowokacyjnie można stwierdzić, że samorząd terytorialny w Polsce stanowi obiekt oddziaływania władz centralnych o tyle, o ile pojawia się koniunktura na decyzje w tym zakresie (m.in. oparta na standardach ponadnarodowych). Początek lat dziewięćdziesiątych to czas, kiedy zainicjowano decentralizację. Dokonania z tamtego okresu są niepodważalne, zabrakło jednak woli i odwagi do tego, aby przekroczyć próg dewolucji. Dominowały wówczas działania bieżące i interesy polityczne oraz silna koncentracja na reformie administracyjnej kraju. W latach dwutysięcznych i następnych decydenci krajowi zwolnili się z obowiązku myślenia holistycznego. Siłą rozpędu i pieniędzmi unijnymi doskonalono w tym czasie gminny aparat wykonawczy, a więc zaledwie wycinek systemu.

Podsumowując, zaprezentowana analiza wskazuje, że współczesny polski samorząd gminny, już w fazie koncepcyjnej (lata osiemdziesiąte XX wieku), kształtowany był na wzór standardów międzynarodowych. Wpływy zewnętrzne były widoczne na przestrzeni minionego ćwierćwiecza i zmieniały się jakościowo wraz z ewolucją kryteriów samorządności terytorialnej, która dokonywała się $\mathrm{w}$ środowisku ponadnarodowym. W ostatnich dziesięciu latach widoczne jest uleganie presji unijnej, które można rozpatrywać w kategoriach „elastyczności”, pozwalającej wykorzystywać szanse pojawiające się w otoczeniu. 